\title{
Potensi Antikoagulan Sari Bawang Putih (Allium sativum) Menggunakan Metode Lee-White dan Apusan Darah
}

\author{
Potential of Anticoagulan Garlic Estract (Allium sativum) Using Lee-White \\ Method and Blood Destruction
}

\author{
Rahmawati*, Muammar Fawwas, Rais Razak, Utami Islamiati \\ Fakultas Farmasi, Universitas Muslim Indonesia \\ Corresponding author: Rahmawati: Email: rahmawati.rahmawati@umi.ac.id
}

\begin{abstract}
ABSTRAK
Bawang putih (Allium sativum L.) mengandung minyak atsiri, senyawa allicin, alliin dan senyawa organosulfur lainnya seperti ajoene yang berperan dalam antikoagulan. Penelitian ini bertujuan untuk menguji aktivitas antikoagulan sari bawang putih menggunakan metode Lee-White dan apusan darah. Pengujian aktivitas antikoagulan dilakukan dengan melihat waktu yang diperlukan darah untuk membeku (Lee-White) setelah penambahan sari bawang putih, etanol 96\% (kontrol negatif) dan EDTA (kontrol positif) serta melihat profil sel darah merah di bawah mikroskop (apusan darah). Dari hasil pengujian menunjukan bahwa sari bawang putih memiliki aktivitas antikoagulan di mana pada metode Lee-White, pembekuan darah kontrol untuk tiga probandus berturut-turut terjadi pada waktu 4 menit, 3 menit 30 detik dan 3 menit 30 detik;untuk kontrol negatif pembekuan terjadi pada waktu 4 menit 30 detik, 2 menit 30 detik dan 2 menit 30 detik serta penambahan EDTA dan sari bawang putih tidak mengalami pembekuan darah (sampai lebih dari 24 jam). Kemudian pada metode apusan darah, preparat darah yang ditambahkan sari bawang putih terlihat sel-selnya berbentuk bulat dan tidak berkelompok.
\end{abstract}

Kata kunci: Bawang putih, antikoagulan, Lee-White, apusan darah.

\begin{abstract}
Garlic (Allium sativum L.) contains essential oils, allicin compounds, alliin and other organosulfur compounds such as ajoene which play a role in anticoagulants. This study aimed to examine the anticoagulant activity of garlic extract using the Lee-White method and blood smear. Anticoagulant activity testing was carried out by looking at the time it took for the blood to freeze after adding garlic juice, 96\% ethanol (negative control) and EDTA (positive control) and looking at the red blood cell profile under a microscope (blood smear). From the test results showed that garlic extract had anticoagulant activity in which the Lee-White method, blood control freezing for three consecutive probes occurred at 4 minutes, 3 minutes 30 seconds and 3 minutes 30 seconds; addition of $96 \%$ ethanol occurred at 4 minutes 30 seconds, 2 minutes 30 seconds and 2 minutes 30 seconds and the addition of EDTA and garlic extract did not experience blood clots. Then in the blood smear method, the red blood cells added with garlic juice look round and not in groups.
\end{abstract}

Keyword: Garlic, anticoagulant, Lee-White, blood smear.

\section{PENDAHULUAN}

Antikoagulan adalah zat untuk mencegah terjadinya pembekuan darah.
Antikogulan dapat pula digunakan pada penderita serangan jantung yang disebabkan oleh trombosis atau gumpalan 
di arteri koroner (Tangkery et al., 2013). Selama lebih dari lima dekade obat antikoagulan yang terdiri dari heparin, antagonis vitamin $\mathrm{K}$ dan turunannya memiliki peran utama dalam pengobatan klinis (Al-Saadi, 2013). Walaupun heparin menunjukan aktivitas antikoagulan yang kuat dan sudah luas digunakan untuk antikoagulan, bukti-bukti klinis menunjukan bahwa terdapat efek samping dari pemakaian heparain antara lain pendarahan dan berpotensi membawa resiko kontaminan virus yang berasal dari hewan (Sinurat et al., 2011).

Penelitian ini bertujuan untuk mencari tumbuhan yang berpotensi sebagai antikoagulan. Bawang putih (Allium sativum L.) merupakan salah satu tanaman yang turun temurun telah digunakan sebagai obat tradisional dan bumbu dapur di Indonesia. Bagian utama dan paling penting dari bawang putih adalah umbinya. Dalam industri makanan, umbi bawang putih dijadikan ekstrak, bubuk atau tepung. Bawang putih mengandung minyak atsiri yang sangat mudah menguap di udara bebas. Minyak atsiri ini diduga mempunyai kemampuan sebagai antibakteri dan antiseptik. Sementara itu, zat yang diduga berperan memberi aroma bawang putih yang khas adalah alisin (hasil penguraian alliin oleh enzim ellinase) yang dapat menurunkan kadar kolesterol, mencegah penyakit jantung dan hipertensi (Srihari et al., 2015). Alisin mengandung sulfur dengan struktur tidak jenuh dan dalam beberapa detik dapat terurai menjadi senyawa dialildisulfida (Cantwell, 2000; Purwaningsih, 2007).

Bawang putih juga mengandung senyawa fenolik yang berguna sebagai antioksidan (Prasonto et al., 2017); kalsium yang dapat mencegah hipertensi, ajoene yang membantu menurunkan kadar kolesterol dalam darah (Untari, 2010), dan sebagai antikoagulan (Davison et al., 2012), serta protein, sulfur dan saltivin (Purwaningsih, 2007). Ajoene menurunkan kecepatan pembekuan darah karena bersifat antikoagulasi. Hal ini secara langsung dapat mengurangi resiko strok dan penyakit kardiovaskuler (Hernawan et al., 2003) Bawang putih juga bermanfaat membantu mengecilkan sumbatan pada arteri jantung sehingga meminimalkan terjadinya serangan jantung (Untari, 2010). Ada dua metode yang dapat digunakan dalam menentukan aktivitas antikoagulan yaitu metode Lee-White dan apusan darah. Metode Lee-White digunakan untuk menentukan lamanya waktu yang diperlukan darah untuk membeku, sedangkan metode apusan darah untuk membantu melihat profil sel darah merah yang mengalami koagulasi maupun yang tidak mengalami koagulasi. Kedua metode ini dianggap lebih mudah untuk dilakukan dan mendapatkan hasil yang lebih cepat (Yayuningsih et al., 2015).

Kandungan minyak dalam bawang putih berkhasiat membersihkan darah dan mengurangi rasa sakit pada bagian tubuh. Bawang putih sering dijadikan ramuan obat asma, menurunkan berat badan, mengontrol kolesterol, gangguan suara serak, nyeri haid, flu, kencing sedikit, demam, batuk rejan, tuberkulosis dan lainlain. Bawang putih banyak digunakan sebagai bumbu utama pada berbagai masakan karena aromanya yang khas. Aroma khas tersebut karena adanya komponen aktif allicin pada bawang putih. Allicin juga berguna untuk daya anti kolesterol yang dapat mencegah penyakit jantung, tekanan darah tinggi dan lain sebagainya. Komponen allicin bersifat volatil sehingga bila penanganannya salah maka dapat menyebabkan kerusakan (Srihari et al., 2015).

Pada bawang putih setelah dikonsumsi komponen allicin (didapatkan setelah allicin berinetraksi dengan enzim allinase) dilepas ke pembuluh darah; pada beberapa studi manusia dan hewan, allicin mampu mencetuskan sel darah merah untuk menghasilkan $\mathrm{H}_{2} \mathrm{~S}$ yang mempunyai 
efek vasodilator (Imelda et al., 2013). Selain itu, hasil penelitian juga menunjukan efek bawang putih dalam menurunkan agregasi platelet yang signifikan dibandingkan plasebo. Bawang putih mempunyai cara kerja seperti asam asetilsalisilat yaitu dapat mengurangi kemampuan pembekuan darah (Imelda et al., 2013).

\section{METODOLOGI}

\section{Alat dan Bahan}

Alat, deck glass, mikropipet (Eppendorf ${ }^{\circledR}$ ), mikroskop binokuler (Olympus CX23), object glass, spoit $5 \mathrm{~mL}$ (Onemed ${ }^{\circledR}$ ), stopwatch, tabung vaculab plain $3 \mathrm{~mL}$, timbangan analitik (Ohaus $\left.{ }^{\circledR}\right)$, torniquet dan vortex portable mixer (Ika ${ }^{\circledR}$ Vortex Genius 3).

Bahan, alkohol 70\%, aquades, darah, EDTA, etanol 96\%, kapas, larutan giemsa, minyak imersi dan sari bawang putih (Allium sativum L.).

\section{Prosedur penelitian}

Penyiapan sampel

Umbi bawang putih (Allium sativum

L.) dikupas, dicuci, dipotong keci-kecil, dihaluskan menggunakan juicer dan diambil sarinya.

Penyiapan sampel uji darah

Tiga orang probandus sehat diambil darahnya dari vena kubiti menggunakan alat suntik disposible $5 \mathrm{~mL}$. Jumlah darah yang diambil pada tiap probandus sebanyak $3 \mathrm{~mL}$.

Penentuan volume sampel untuk pengujian

Disiapkan 5 tabung vaculab plain 3 $\mathrm{mL}$ yang diisi masing-masing $1 \mathrm{~mL}$ darah. Setiap tabung ditambahkan sampel dengan variasi volume, yaitu 20, 40, 60, 80 dan 100 $\mu \mathrm{l}$, diinkubasi selama 3 menit untuk melihat terjadinya koagulasi. Hasilnya, hanya tabung yang ditambahkan $80 \mu \mathrm{l}$ sampel yang tidak mengalami koagulasi (Tangkery et al., 2013).
Pengujian aktivitas antikoagulasi Sari Bawang Putih Pada Sampel Uji Darah (Tangkery et al., 2013)

Metode yang digunakan dalam pengujian ini ada 2 yaitu, metode Lee-White metode ini digunakan untuk menentukan waktu pembekuan darah yang diamati secara visual (berdasarkan masa pembekuan darah normal) dan metode apusan darah, dengan berbagai perlakuan yaitu sampel darah sebagai kontrol, etanol 96\% sebagai kontrol negatif, EDTA sebagai kontrol positif, sari bawang putih sebagai perlakuan pertama dan sari bawang putih dan EDTA sebagai perlakuan kedua.

\section{Prosedur metode Lee-White}

Pada tabung (1) : $1 \mathrm{~mL}$ darah, lalu stopwatch dijalankan untuk melihat waktu pembekuan darah (darah kontrol).

Pada tabung (2) : $1 \mathrm{~mL}$ darah dan 100 $\mu \mathrm{l}$ etanol 96\% (kontrol negatif).

Pada tabung (3) : $1 \mathrm{~mL}$ darah dan $1 \mathrm{mg}$ EDTA (kontrol positif).

EDTA merupakan antikoagulan yang dapat mengikat kalsium sehingga tidak dapat berperan dalam proses pembekuan. EDTA yang dibutuhkan untuk mengikat kalsium yaitu 1 - $2 \mathrm{mg} / 1 \mathrm{~mL}$ darah.

Pada tabung (4) : $1 \mathrm{~mL}$ darah dan 100 $\mu \mathrm{l}$ sari bawang putih (perlakuan pertama).

Pada tabung (5) : dimasukkan $1 \mathrm{~mL}$ darah dan ditambahkan $100 \mu \mathrm{l}$ sari bawang putih dan 1 mg EDTA (perlakuan kedua).

Stopwatch dijalankan untuk menentukan waktu pembekuan darah Setelah 3 menit tabung diangkat dan masing-masing tabung reaksi dimiringkan untuk melihat apakah sudah terjadi pembekuan atau belum. Bila belum terjadi pembekuan, letakkan kembali pada rak tabung dan dilakukan pengamatan setiap 30 detik.

\section{Metode Apusan Darah}

Efek pembekuan darah juga dapat dilihat secara mikrosokopik. Metode ini 
Tabel I. Hasil pengamatan waktu koagulasi

\begin{tabular}{cllccc}
\hline \multirow{2}{*}{ Probandus } & \multicolumn{5}{c}{ Waktu pengamatan } \\
\cline { 2 - 6 } & \multicolumn{1}{c}{ T1 } & T2 & T3 & T4 & T5 \\
\hline I (A) & 4 menit & 4 menit 30 detik & - & - & - \\
II (B) & 3 menit 30 detik & 2 menit 30 detik & - & - & - \\
III (C) & 3 menit 30 detik & 2 menit 30 detik & - & - & - \\
\hline
\end{tabular}

Keterangan: T1: Darah (control); T2: Darah ditambah Etanol 96\% (kontrol negatif); T3: Darah ditambah EDTA (control positif); T4: Darah ditambah sari bawang putih (perlakuan pertama); T5: Data ditambah EDTA dan sari bawang putih (perlakuan kedua); ( - ): Tidak jadi perlakuan.

dilakukan untuk melihat keadaan sel darah secara mikroskopik. Sampel yang digunakan pada pengujian ini diambil dari tabung pada metode Lee-White di atas.

Disiapkan 5 buah object glass yang bersih dan tidak berlemak dan masingmasing diberi label nomor 1 sampai 5 . Dipipet darah pada masing-masing tabung reaksi sebanyak $20 \mu \mathrm{l}$ dan ditotolkan pada 5 buah object glass secara berurutan.Tetesan darah pada object glass disentuh dengan deck glass dengan posisi miring, kemudian digeser ke arah berlawanan. Preparat difiksasi dalam larutan metanol sampai menutupi bagian permukaannya selama 15 menit dan diangin-anginkan sampai kering. Preparat kemudian direndam dalam larutan giemsa selama 30 menit dan dibilas dengan air, selanjutnya diangin-anginkan sampai mengering. Preparat ditetesi dengan minyak imersi dan ditutup menggunakan deck glass. Hasilnya diamati di bawah mikroskop dengan pembesaran 400x dan didokumentasikan dengan kamera.

\section{HASIL DAN PEMBAHASAN}

Hasil uji aktivitas antikoagulan sari bawang putih (Allium sativum L.) dengan menggunakan metode Lee-White dan hapusan darah (Tabel I).

\section{Metode Lee - White}

Berdasarkan tabel hasil pengamatan di atas, waktu koagulasi darah ketiga probandus tersebut agak berbeda. Menurut (Corwin, 2009) waktu pembekuan darah (koagulasi) tidak lebih dari 15 menit, normalnya 3-9,5 menit untuk penusukan lengan. Sampel darah kontrol dari ketiga probandus masih dalam waktu koagulasi normal begitupun dengan sampel darah yang ditambahkan etanol 96\%. Di mana etanol 96\% tidak mempengaruhi proses koagulasi darah normal. Hasil darah yang mengalami pembekuan (koagulasi) (Gambar 1).

Proses pembekuan darah (koagulasi) tidak terjadi pada tabung ketiga (T3) yang berisi darah ditambahkan EDTA sebagai kontrol positif, tabung keempat (T4) yang berisi darah ditambahkan sari bawang putih sebagai perlakuan pertama (P1) dan tabung kelima yang berisi darah ditambahkan sari bawang putih dan EDTA sebagai perlakuan kedua (P2). Hal ini menunjukan bahwa sari bawang putih dapat dijadikan sebagai antikoagulan. Tidak terjadinya proses koagulasi pada darah yang ditambahkan sari bawang putih dan EDTA (Gambar 2).

Menurut Imelda \& Kurniawan (2013) komponen allicin pada bawang putih akan dilepas ke pembuluh darah, allicin mampu mencetuskan sel darah merah untuk menghasilkan $\mathrm{H}_{2} \mathrm{~S}$ yang mempunyai efek vasodilator. Senyawa aktif umbi bawang putih seperti kelompok ajoene akan menghambat ion $\mathrm{Ca}^{2+}$ yang berperan dalam kontraksi otot jantung dan otot polos pembuluh darah, sehingga cairan intraseluler menurun dan terjadi relaksasi yang menyebabkan ruangan dalam pembuluh darah melebar (Hernawan \& 

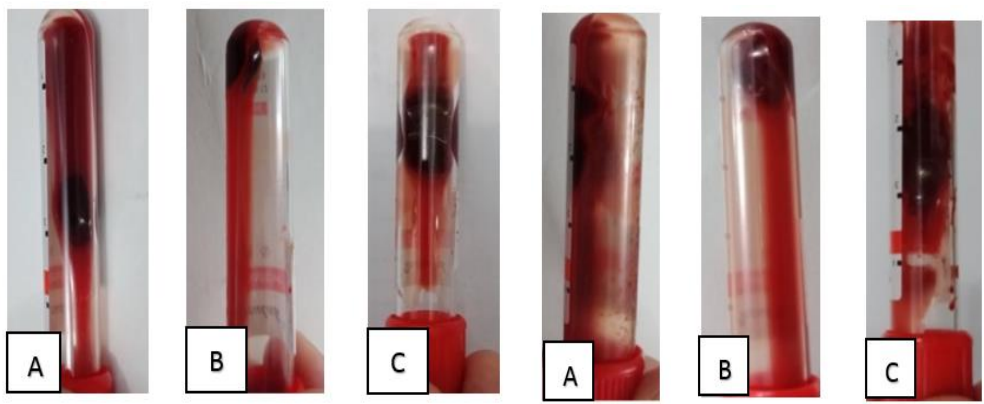

Gambar 1. Darah kontrol dan kontrol negatif: probandus I (A); probandus II (B); probandus III (C)
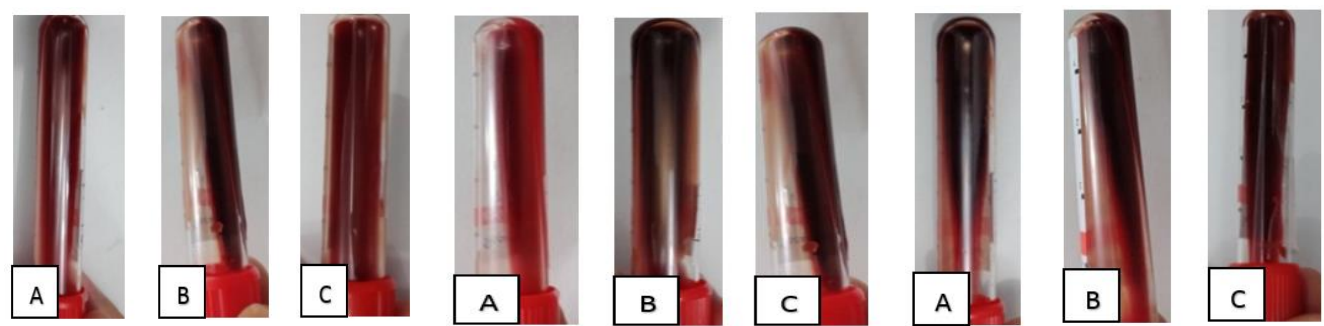

Gambar 2. Kontrol Positif, perlakuan pertama dan kedua: probandus I (A); probandus II (B); probandus III (C)

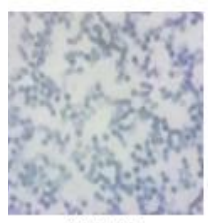

(AT1)

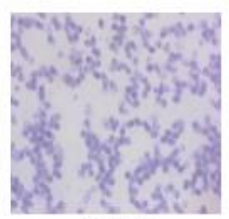

(BT1)

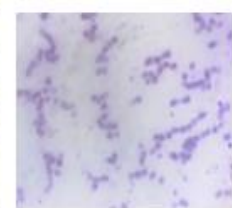

(CT1)

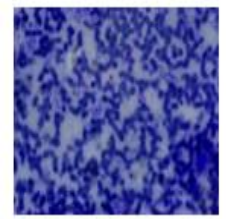

(AT2)

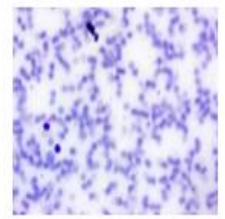

(BT2)

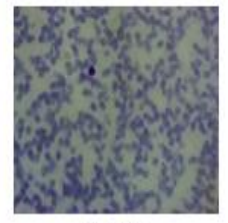

(CT2)

(kontrol positif)

Gambar 3. Preparat darah kontrol positif dan kontrol negatif: AT1, BT1, CT1 dan AT2, BT2, CT2

Setyawan, 2003). EDTA bekerja dengan cara mengikat ion $\mathrm{Ca}^{2+}$ yang dibutuhkan untuk proses pembekuan darah (koagulasi) (Fitria, 2013).

\section{Metode apusan darah}

Aktivitas pembekuan darah juga dapat dilihat dengan metode hapusan darah dengan melihat profil sel darah merah di bawah mikroskop. Berdasarkan Gambar 3 yaitu preparat darah kontrol probandus pertama tabung pertama (AT1), probandus kedua tabung pertama (BT1) dan probandus ketiga tabung pertama (CT1) sera yaitu preparat darah (kontrol negatif) probandus pertama tabung kedua (AT2), probandus kedua tabung kedua (BT2) dan probandus ketiga tabung kedua (CT2), tampak sel darah merah yang tidak terpisah satu sama lain karena mengalami koagulasi. Sel darah yang mengalami koagulasi akan tampak padat dan berkelompok.

Preparat darah kontrol positif ketiga probandus (Gambar 4), perlakuan pertama dan perlakuan kedua (Gambar 5), terlihat pada masing-masing gambar bentuk sel darah merah yang tidak mengalami koagulasi tampak berbentuk bulat, tidak saling berkaitan dan berdiri sendiri dengan ukuran yang sama satu dengan lainnya. 


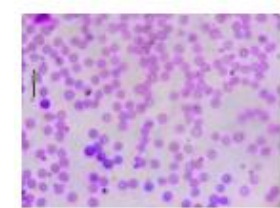

(AT3)

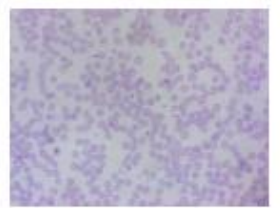

(BT3)

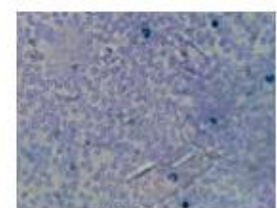

(CT3)

Gambar 4. Preparat kontrol positif: AT3, BT3, CT3

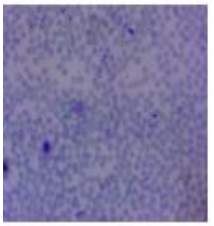

(AT4)

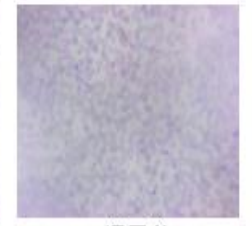

(BT4)

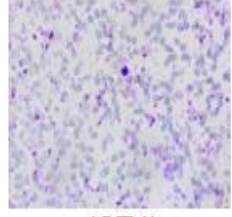

(CT4)

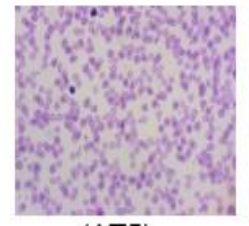

(AT5)

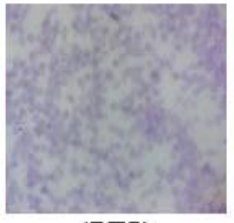

(BT5)

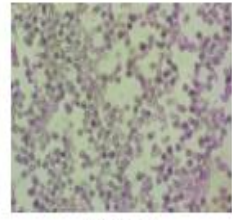

(CT5)

(Perlakuan Pertama)

Gambar 5. Preparat perlakuan pertama dan kedua: AT4, BT4, CT4 dan AT5, BT5, CT5

Bentuk sel darah merah yang tidak membeku tampak berbentuk bulat, memiliki inti yang kosong dan tidak berkelompok.

\section{KESIMPULAN}

Berdasarkan hasil yang diperoleh, dapat disimpulkan bahwa sari bawang putih (Allium sativum L.) memiliki aktivitas sebagai antikoagulan yang dapat mencegah pembentukan bekuan darah (koagulasi).

\section{DAFTAR PUSTAKA}

Al-Saadi, NHM 2013, 'In Vitro study Of The Anticoagulant Activity Of Some Plant Extracts', Indian Journal Applied Research, vol. 3, no 7.

Cantwell,,M 2000, Alliin in garlic, Department of vegetable crops, UCD, Perishables handling quarterly issue, No.102

Corwin, EJ 2009, Buku saku patofisiologi, 3rd edn, EGC, Jakarta.

Davison C, Levendal, RA, Frost, CL, 2012, Cardiovascular benefits of an organic extract of Thulbaghia violacea: Its anticoagulant and anti-platelet properties, Journalof medicine plants research, vol.6 (33), pp.4815-4824.

Hernawan, UE \& Setyawan, AD 2003, Review: 'Senyawa Organosulfur
Bawang Putih (Allium sativum L.) dan Aktivitas Biologinya', Biofarmasi, vol. 1, no. 2, hal 65-76.

Imelda, M \& Kurniawan, S 2013, 'Peranan Garlic (Bawang Putih) pada Pengelolaan Hipertensi', CDK-209/ vol. 40, no. 1 .

Prasonto, E, Riyanti, E \& Meirina, G 2017, 'Uji Aktivitas Antioksidan Ekstrak Bawang Putih', Odonto Dental Journal, vol. 4 , no. 2.

Purwaningsih, E 2007, Bawang Putih, Edisi Pertama, Ina Parawita Sari, Ganeca Exact.

Srihari, E, Lingganinggrum, FS, Damaiyanti, D \& Fanggih, N 2015, 'Ekstrak Bawang Putih Bubuk Dengan Menggunakan Proses Spray drying', Jurnal Teknik Kimia, vol. 9, no. 2.

Sinurat, E, Peranginangin, R, Saepudin, E 2011, 'Ekstraksi dan Uji Aktivitas Fukoidan Dari Rumput Laut Coklat (Sargassum crassifoilium) Sebagai Antikoagulan' Jurnal Pascapanen dan Bioteknologi Kelautan dan Perikanan, vol. 6, no. 2.

Tangkery, RAB, Paransa, DS \& Rumengan, A 2013, 'Uji Aktivitas

Antikoagulan Ekstrak Mangrove (Aegiceras corniculatum)', Jurnal Pesisir dan Laut Tropis, vol. 1, no. 1. 
Rahmawati

Untari, I 2010, 'Bawang Putih Sebagai Obat Paling Mujarab Bagi Kesehatan', Gaster, vol. 7, no. 1.

Yayuningsih, D, Farihatun, A, Fitria, Melhax
2015, Perbedaan Waktu pembekuan Metode Lee and White Dan Metode hapusan darah, STIKES Muhammadiyah, Ciamis. 